\title{
Analysis on Job Burnout Level and Influencing Factors of Young Employees in Guangdong Express Delivery Industry
}

\author{
Chunshu Liang ${ }^{1, *}$ Jing Chen ${ }^{1}$
}

\author{
${ }^{1}$ Department of Business Administration, Guangzhou College of Technology and Business, Guangzhou, Guangdong \\ 510800, China \\ *Corresponding author. Email: LCS084@126.com
}

\begin{abstract}
In the express delivery industry, young employees are vulnerable to job burnout. According to the analysis of the survey results of job burnout among young employees in the express delivery industry in Guangdong province, it can be seen that there is a moderate level of job burnout among young employees in the express delivery industry in Guangdong province. From the results of the survey and analysis, there are significant differences in the levels of job burnout among young employees of different genders, ages, education levels, years of work, positional levels and monthly income. Through further regression analysis, it is found that among the independent variables of physical and mental health, workload, environmental stress, values, compensation and benefits, promotion training and interpersonal relationships, the impact of workload and interpersonal relationships have the greatest impact on job burnout among young employees in Guangdong province. When it comes to the three dimensions of job burnout, workload and values have a significant relationship with emotional exhaustion; workload, environmental stress, promotion training, physical and mental health and interpersonal and depersonalized relationships are significant; physical and mental health, interpersonal relationships and low achievement are significantly related. Enterprises should improve the working environment, reduce the workload, enrich the work content, improve the incentive mechanism and promotion mechanism and create a harmonious corporate competition culture to achieve the purpose of reducing the occurrence of young employees' job burnout.
\end{abstract}

\section{Keywords: young employees, job burnout, depersonalization, low accomplishment, emotional failure}

\section{INTRODUCTION}

As a highly developed economy, Guangdong has a huge business volume in the online retail market and a booming express delivery industry. According to statistics, in 2019, the express delivery business volume of Guangdong province reached 1,680,594 ten thousand pieces, accounting for $26.46 \%$ of the country's total business volume. The double-digit increase in business volume each year has caused the overwork phenomenon of express delivery workers to be more common. The survey report shows that express delivery workers work 8-10 hours every day, accounting for $46.85 \%$, and those who work more than 12 hours almost reach $20 \%$. Large workloads, long hours and few breaks are the norm for most express delivery workers. Survey data show that $75 \%$ of the express delivery employees' monthly income is below 5,000 yuan, and only $0.73 \%$ of them have a monthly income of more than 10,000 yuan. Express delivery employees' pay is linked to the volume of delivery ${ }^{1}$. As the tertiary industry, the express delivery industry belongs to the service industry in essence. It has particularly high requirements for the quality of employees, which also brings great pressure to the employees.

The heavy workload, long time, low income and high pressure have greatly affected the physical and mental health of employees, and caused different degrees of job burnout. It is manifested as physical and mental fatigue, emotional exhaustion, decreased responsibility, poor work attitude, lack of sense of achievement, etc. Young employees belong to vulnerable groups. Young employees are the backbone of the express delivery industry. Reducing the job burnout of young employees will play an important role

Source (Internet): Title: The report shows the real situation of the courier: monthly income over 10,000 accounts for only $0.73 \%$ https://baijiahao.baidu.com/s?id=1654863843852992990\&wfr=spider $\&$ for $=$ pc. 
in the healthy and sustainable development of the express delivery industry in China.

\section{LITERATURE REVIEW AND RESEARCH HYPOTHESIS}

Social psychologist Maslach defines job burnout as "the symptoms of emotional exhaustion, disintegration of personality, and decreased sense of accomplishment that occur in individuals in the professional field that serves people". Initially, researchers proposed that job burnout is to pay attention to the emotions, motivations and value orientations of service employees. With the expansion of the research object, it is found that the phenomenon of job burnout exists in all walks of life. It is a kind of psychological extreme reaction of employees under long-term work pressure. It is mainly manifested by slowly losing interest in work, physical and mental fatigue, decreased responsibility and low sense of achievement.

In 1981, Maslach and others compiled the MBI-GS Scale (Maslach Burnout Inventory-General Survey) to measure job burnout and use questionnaires to study the problem of job burnout. A revised version of the MBI scale was published in 1996. In this scale, the respondents' job burnout was measured from three dimensions (emotional failure, depersonalization, and lack of sense of achievement). Among them, emotional failure is the key dimension, mainly measuring the emotional exhaustion of the respondents. The depersonalization dimension mainly measures the sense of responsibility and work attitude that the respondents lose in the group work, and the lack of achievement dimension measures the respondents' perception of work value and competence. Chinese scholars $\mathrm{Li}$ Chaoping and Shi Kan (2003) obtained authorization from Maslach, and revised the MBI-GS in accordance with China's national conditions to form a Chinese version of the MBI-GS scale with 15 questions in three dimensions.

At the end of the last century, the research field of job burnout continued to expand. Scholars began to apply complex research methods such as structural equation methods to explore the complex relationship between job burnout and organizations, and even to study the underlying factors of job burnout and the negative effects that it may bring. They also tried to explore the mitigation effect of control variables on job burnout through vertical tracking methods. Leiter \& Maslach (2001) proposed the theory of influencing factors on job burnout. The study suggested that the mismatch between workload, feeling of control, pay, fairness, communication, and values was positively related to job burnout. Since then, scholars have carried out research from various angles. HaiyanKong et al. (2016), when studying the relationship between job burnout and age, showed that there is a clear correlation between the two, and the degree of job burnout among young employees is generally higher than that of older employees. Research by Yu Jufen et al. (2014) found that clinical burnout among clinical nurses has a significant relationship with their professional values. Chen Lulu et al. (2016) found that the greater the work stress of an individual, the more prone to job burnout. Jin Renmin et al. (2016) found through research that interpersonal relationships were negatively related to job burnout. Disharmony between leader-member relationship and colleague relationships is most likely to cause job burnout. Zhao Lanfang's (2017) research found that excessive workload leads to high employee stress and easily causes job burnout. Zhang Yan (2018) surveyed the employees of the group and found that physical discomfort is one of the causes of employees' job burnout. Han Jing et al. (2018) used clinicians as the research object and found that there was a significant negative correlation between organizational support and job burnout. Li Rongyu (2018) studied the auxiliary burnout problem of auxiliary police officers, and the results showed that gender, age, salary level and working years had significant effects on the job burnout of auxiliary police officers. Liu Bingfan's (2019) research found that the more extroverted the employees, the more stable their emotions, the easier they are to communicate and the weaker their concealment, the less prone to job burnout. Conversely, employees who are introverted, emotionally fragile, and good at concealing themselves are more prone to job burnout. In short, a large number of studies show that job burnout is not only deeply affected by individual factors, but also by organizational factors.

Based on the existing literature review, the following research hypotheses are put forward:

Hypothesis 1: There is a significant gap in the level of job burnout among young employees in the express delivery industry at different ages, education levels, years of working and income;

Hypothesis 2: Physical and mental health, workload, environmental stress, values, compensation and benefits, promotion training and interpersonal relationships have significant effects on the level of job burnout (emotional failure, depersonalization and low sense of achievement) of young employees in the express delivery industry.

\section{RESEARCH DESIGN}

\section{A. Research object}

This article selects young employees who are engaged in the express delivery industry in Guangdong province as the research object and uses a simple random sampling method to conduct a network questionnaire survey. A total of 200 survey samples are obtained. 


\section{B. Questionnaire design}

In order to conduct a more objective investigation, a questionnaire on job burnout of young employees in the express delivery industry in Guangdong province is designed. The questionnaire is divided into 3 parts with a total of 43 questions. The first part is basic information with a total of 7 questions, including demographic characteristics, work conditions and other information of the respondents; the second part is a job burnout survey using the "MBI-GS Scale" revised by Li Chaoping and others, including 15 questions in 3 dimensions: emotional failure, depersonalization, and sense of achievement. A five-point scoring method is used for each question. The five degree options are "rare", "occasional", "often", "frequent" and "very frequent", and the scores are from 1 to 5 points respectively. The third part is the influencing factors of job burnout. There are 21 questions in 7 dimensions, including physical and mental health, workload, values, environmental pressures, compensation and benefits, promotion training and interpersonal relationships. Each question uses a 5-point scoring method, which includes very disagree, disagree, uncertainty, agree and strongly agree, and the scores are from 1 to 5 points respectively. Among them, the low achievement dimension is inversely proportional to the degree of burnout. The higher the score, the lighter the degree of burnout.

\section{EMPIRICAL ANALYSIS AND RESULTS}

\section{A. Reliability and validity test}

The survey results are analyzed statistically using SPSS26.0. The multiple dimensions are measured by 3 or more questions, so the reliability and validity tests are performed on these scale questions. The test results are shown in "Table I". From the test results, the validity is greater than 0.7 , and further factor analysis can be performed to obtain factor scores for regression analysis.

TABLE I. RELIABILITY AND VALIDITY TEST RESULTS

\begin{tabular}{|c|c|c|c|c|c|c|c|}
\hline \multirow[b]{2}{*}{$\begin{array}{l}\text { Measured } \\
\text { variable }\end{array}$} & \multicolumn{2}{|c|}{ Reliability test } & \multicolumn{3}{|c|}{ Validity test } & \multicolumn{2}{|c|}{ Factor analysis results } \\
\hline & $\begin{array}{c}\text { Cronbach } \alpha \\
\text { coefficient }\end{array}$ & Number of items & $\begin{array}{l}\text { KMO and } \\
\text { Bartlett test }\end{array}$ & $\begin{array}{l}\text { Approximate } \\
\text { chi-square }\end{array}$ & Sig. & $\begin{array}{l}\text { Common } \\
\text { factor }\end{array}$ & $\begin{array}{c}\text { Loading of } \\
\text { quadratic sum } \\
\text { (cumulative \%) }\end{array}$ \\
\hline Job burnout & 0.803 & 15 & 0.896 & 3481.651 & 0.000 & 3 & 84.503 \\
\hline Emotional failure & 0.945 & 5 & 0.879 & 1010.647 & 0.000 & 1 & 83.190 \\
\hline Depersonalization & 0.915 & 4 & 0.803 & 588.576 & 0.000 & 1 & 79.845 \\
\hline $\begin{array}{c}\text { Low sense of } \\
\text { accomplishment }\end{array}$ & 0.969 & 6 & 0.911 & 1552.984 & 0.000 & 1 & 86.605 \\
\hline $\begin{array}{l}\text { Physical and } \\
\text { mental health }\end{array}$ & 0.882 & 3 & 0.704 & 369.730 & 0.000 & 1 & 81.336 \\
\hline Workload & 0.822 & 3 & 0.703 & 221.807 & 0.000 & 1 & 73.888 \\
\hline $\begin{array}{c}\text { Environmental } \\
\text { pressure }\end{array}$ & 0.827 & 3 & 0.708 & 237.812 & 0.000 & 1 & 75.210 \\
\hline Values & 0.870 & 3 & 0.738 & 0.738 & 0.000 & 1 & 79.328 \\
\hline $\begin{array}{c}\text { Compensation and } \\
\text { benefits }\end{array}$ & 0.878 & 3 & 0.739 & 314.884 & 0.000 & 1 & 80.513 \\
\hline Promotion training & 0.832 & 3 & 0.718 & 238.274 & 0.000 & 1 & 75.489 \\
\hline $\begin{array}{c}\text { Interpersonal } \\
\text { relationship } \\
\end{array}$ & 0.891 & 3 & 0.748 & 345.594 & 0.000 & 1 & 82.274 \\
\hline
\end{tabular}

\section{B. Basic situation of the survey sample}

In this survey, a total of 200 valid questionnaires are collected. The basic situation is shown in "Table II" by sorting and analyzing the sample data.

\section{Descriptive statistical analysis}

The results of descriptive statistical analysis of job burnout and its influencing factors are shown in "Table III". It can be seen that the overall average burnout level of young employees in the express job industry in Guangdong province is 2.481 , which is lower than the median value of 3 , indicating that there is a problem of job burnout but it is not very serious. Among them, the average value of low achievement is the highest, which is 2.858; the average value of emotional failure is second, which is 2.515 , and the average value of depersonalization is the lowest, which is 2.07. In addition, according to the "Table III", the physical and mental health of the employees in the express delivery industry in Guangdong province is good, with an average of 3.768; the workload is heavy with an average of 3.46 ; the environmental pressure is large with an average of 3.13; the satisfaction with salary and benefits is low with an average of 2.145, which is much lower than the median value of 3 . 
TABLE II. BASIC SITUATION OF SURVEY SAMPLES OF YOUNG EMPLOYEES IN THE EXPRESS DELIVERY INDUSTRY IN GUANGDONG PROVINCE

\begin{tabular}{|c|c|c|c|}
\hline Attributes & Category & Frequency & Percentage \% \\
\hline \multirow{2}{*}{ Gender } & Male & 101 & 50.5 \\
\hline & Female & 99 & 49.5 \\
\hline \multirow{4}{*}{ Age } & 20 and under 20 & 23 & 11.5 \\
\hline & $21-25$ & 88 & 44.0 \\
\hline & $26-30$ & 58 & 29.0 \\
\hline & $31-35$ & 31 & 15.5 \\
\hline \multirow{4}{*}{ Education level } & High school and below & 43 & 21.5 \\
\hline & Junior college & 124 & 62.0 \\
\hline & Undergraduate & 31 & 15.5 \\
\hline & Postgraduates and above & 2 & 1.0 \\
\hline \multirow{4}{*}{ Years of working } & Within 3 years & 101 & 50.5 \\
\hline & 4-6 years & 64 & 32 \\
\hline & $7-9$ years & 25 & 12.5 \\
\hline & Above 10 years & 10 & 5.0 \\
\hline \multirow{2}{*}{ Marital status } & Spinsterhood & 147 & 73.5 \\
\hline & Married & 53 & 26.5 \\
\hline \multirow{4}{*}{ Positional level } & Front-line worker & 61 & 30.5 \\
\hline & Low-level manager & 60 & 30.0 \\
\hline & Middle-level manager & 48 & 24.0 \\
\hline & Senior-level manager & 31 & 15.5 \\
\hline \multirow{4}{*}{ Monthly income } & Less than 2500 yuan & 10 & 5.0 \\
\hline & 2501-4000 yuan & 43 & 21.5 \\
\hline & 4001-6000 yuan & 97 & 48.5 \\
\hline & More than 6001 yuan & 50 & 25.0 \\
\hline
\end{tabular}

TABLE III. DESCRIPTIVE STATISTICAL ANALYSIS RESULTS AND INFLUENCING FACTORS OF JOB BURNOUT

\begin{tabular}{|c|l|l|l|l|l|}
\hline \multicolumn{2}{|c|}{ Variable } & Minimum & Maximum & \multicolumn{1}{c|}{ Mean } & Standard deviation \\
\hline \multirow{3}{*}{ Job burnout } & Emotional failure & 1 & 5 & 2.515 & 0.856 \\
\cline { 2 - 5 } & Depersonalization & 1 & 5 & 2.07 & 0.735 \\
\cline { 2 - 5 } & $\begin{array}{c}\text { Low sense of } \\
\text { accomplishment }\end{array}$ & 1 & 5 & 2.858 & 1.079 \\
\cline { 2 - 5 } Overall level & 1 & 5 & 2.481 & 0.513 \\
\hline Physical and mental health & 1 & 5 & 3.768 & 0.699 \\
\hline Workload & 2 & 5 & 3.460 & 0.653 \\
\hline Environmental pressure & 1 & 5 & 3.130 & 0.774 \\
\hline Values & 1 & 5 & 3.113 & 0.714 \\
\hline Compensation and benefits & 1 & 5 & 2.145 & 0.734 \\
\hline Promotion training & 1 & 5 & 3.010 & 0.672 \\
\hline
\end{tabular}

\section{Difference analysis results}

In order to test whether there are differences in job burnout among young employees in the express delivery industry in Guangdong province with different demographic variables, independent T-sample tests and one-way analysis of variance are performed on multiple sample means.

The independent sample $\mathrm{T}$ test on gender and marital status finds that there is a significant difference in emotional failure and depersonalization of young employees of different genders $(\mathrm{P}<0.05)$. The level of emotional failure and depersonalization of male employees is higher than that of female employees. There is no significant difference in the sense of low achievement between male and female employees $(\mathrm{P}>$ $0.05)$. There is a significant difference in the level of job burnout among unmarried employees and married employees $(\mathrm{P}<0.05)$. The average values of emotional failure, depersonalization, and low sense of accomplishment of unmarried employees are higher than those of married employees (see "Table IV"). 
TABLE IV. JOB BURNOUT LEVELS OF YOUNG EMPLOYEES OF DIFFERENT GENDERS AND MARITAL STATUS

\begin{tabular}{|c|c|c|c|c|c|}
\hline Factor & Gender & Number of cases & Mean & Standard deviation & Sig. (Two-tailed) \\
\hline \multirow{2}{*}{ Emotional failure } & Male & 101 & 2.655 & 0.891 & \multirow{2}{*}{0.019} \\
\hline & Female & 99 & 2.372 & 0.797 & \\
\hline \multirow{2}{*}{ Depersonalization } & Male & 101 & 2.238 & 0.807 & \multirow{2}{*}{0.001} \\
\hline & Female & 99 & 1.899 & 0.612 & \\
\hline \multirow{2}{*}{ Low sense of accomplishment } & Male & 101 & 3.238 & 1.008 & \multirow{2}{*}{0.209} \\
\hline & Female & 99 & 3.046 & 1.144 & \\
\hline \multirow[t]{2}{*}{ Emotional failure } & Spinsterhood & 147 & 2.661 & 0.863 & \multirow[t]{2}{*}{0.000} \\
\hline & Married & 53 & 2.109 & 0.695 & \\
\hline \multirow[t]{2}{*}{ Depersonalization } & Spinsterhood & 147 & 2.177 & 0.715 & \multirow[t]{2}{*}{0.001} \\
\hline & Married & 53 & 1.774 & 0.716 & \\
\hline \multirow[t]{2}{*}{ Low sense of accomplishment } & Spinsterhood & 147 & 3.463 & 0.922 & \multirow[t]{2}{*}{0.000} \\
\hline & Married & 53 & 2.255 & 0.987 & \\
\hline
\end{tabular}

A one-way analysis of variance on age, education level, years of work, job level, and monthly income finds that young employees of different ages, education levels, working years, job levels and monthly income all have significant differences in the three dimensions of emotional failure, depersonalization and low sense of achievement $(\mathrm{P}<0.01)$. Specifically, the emotional failure and depersonalization level of employees under 20 years of age are significantly higher than those of other age groups, and the highest level of low achievement level is among 21-25 years old employees (see "Table V"). In terms of education level, the order of emotional failure from high to low of young employees is as follows: high school and below (3.04) $>$ junior college (2.39) $>$ undergraduate $(2.37)>$ master (1.4); the order of depersonalization from high to low is: high school and below (2.62) > undergraduate (1.94) $>$ junior college (1.93) > master (1.13); the order of low accomplishment from high to low is: high school and below (3.72) > junior college $(3.07)>$ undergraduate $(2.73)>$ master $(1.5)$. From the perspective of working years, the highest emotional failure and personalization of young employees are those with working years of less than 3 years $(2.82,2.27)$, and the rest are $4-6$ years $(2.24,1.96), 7-9$ years. $(2.12,1.7)$ and 10 years and above $(2.18,1.7)$; the highest level of low achievement is employees with working years of 7-9 years (4.27), followed by employees with working years of more than 10 years (3.77), followed by employees with working years of 4-6 years (3.33) and the lowest is employees within working years of 3 years (2.12).

From the positional level, front-line workers have the highest levels of emotional failure and low sense of achievement $(3.18,3.80)$, followed by low-level managers $(2.34,3.74)$, followed by middle-level managers $(2.18,2.39)$, and the lowest is senior-level managers $(2.06,1.88)$; the highest level of depersonalization is front-line workers $(2.70)$, followed by middle-level managers (1.90), followed by low-level managers (1.82), and the lowest is senior-level managers (1.57).
From the perspective of monthly income level, employees with monthly income in the range of 2501 4000 yuan have the highest levels of emotional failure, depersonalization and low sense of achievement (3.22, $2.62,3.78$ ), followed by employees with monthly income below 2500 yuan $(2.82,2.53,3.58)$, followed by employees with monthly income of 4001-6000 yuan $(2.4,1.96,3.4)$, followed by employees with monthly income of more than 6001 yuan $(2.06,1.73,2.003)$

\section{E. Correlation analysis}

The relevant analysis of emotional failure, depersonalization, low sense of achievement and influencing factors (physical and mental health, workload, environmental pressure, values, compensation and benefits, promotion training, and interpersonal relationships) of young employees in the express industry in Guangdong province finds that emotional failure is highly positively related to depersonalization, workload, and environmental stress, and highly negatively related to physical and mental health, values, promotion training, and interpersonal relationships; depersonalization is highly positively related to emotional failure, workload, and environmental stress, and is highly negatively related to physical and mental health, values, compensation and benefits, promotion training, and interpersonal relationships; low sense of achievement (the larger the value, the lower the job burnout) is significantly positively related to physical and mental health, values, promotion training, and interpersonal relationships, and is significantly negatively related to workload and environmental stress. Next, regression analysis is performed to further verify the results. 
TABLE V. JOB BURNOUT LEVELS OF EMPLOYEES AT DIFFERENT AGES

\begin{tabular}{|c|c|c|c|c|c|}
\hline Factor & Age & Number of cases & Mean & Standard deviation & Sig. (Two-tailed) \\
\hline \multirow{4}{*}{ Emotional failure } & 20 and under 20 & 23 & 3.1130 & 0.92604 & \multirow{4}{*}{0.000} \\
\hline & $21-25$ & 88 & 2.7000 & 0.83432 & \\
\hline & $26-30$ & 58 & 2.2138 & 0.74350 & \\
\hline & $31-35$ & 31 & 2.1097 & 0.66501 & \\
\hline \multirow{4}{*}{ Depersonalization } & 20 and under 20 & 23 & 2.4783 & 0.80451 & \multirow{4}{*}{0.000} \\
\hline & $21-25$ & 88 & 2.2216 & 0.81070 & \\
\hline & $26-30$ & 58 & 1.8836 & 0.53643 & \\
\hline & $31-35$ & 31 & 1.6855 & 0.49568 & \\
\hline \multirow{4}{*}{ Low sense of accomplishment } & 20 and under 20 & 23 & 3.7246 & 0.71175 & \multirow{4}{*}{0.000} \\
\hline & $21-25$ & 88 & 3.8030 & 0.70373 & \\
\hline & $26-30$ & 58 & 2.5230 & 0.85922 & \\
\hline & $31-35$ & 31 & 1.9946 & 0.93242 & \\
\hline
\end{tabular}

TABLE VI. CORRELATION COEFFICIENTS OF MAJOR VARIABLES

\begin{tabular}{|c|c|c|c|c|c|c|c|c|c|c|}
\hline & $\begin{array}{c}\text { Emotional } \\
\text { failure }\end{array}$ & $\begin{array}{c}\text { Depersonali } \\
\text { zation }\end{array}$ & $\begin{array}{c}\text { Low sense } \\
\text { of } \\
\text { accomplish } \\
\text { ment }\end{array}$ & $\begin{array}{c}\text { Physical } \\
\text { and mental } \\
\text { health }\end{array}$ & Workload & $\begin{array}{c}\text { Environme } \\
\text { ntal } \\
\text { pressure }\end{array}$ & Values & $\begin{array}{l}\text { Compensation } \\
\text { and benefits }\end{array}$ & $\begin{array}{c}\text { Promotion } \\
\text { training }\end{array}$ & $\begin{array}{c}\text { Interperson } \\
\text { al } \\
\text { relationship }\end{array}$ \\
\hline $\begin{array}{l}\text { Emotional } \\
\text { failure }\end{array}$ & 1 & & & & & & & & & \\
\hline $\begin{array}{c}\text { Depersonaliz } \\
\text { ation }\end{array}$ & $670 * *$ & 1 & & & & & & & & \\
\hline \begin{tabular}{|c|} 
Low sense of \\
accomplish \\
ment
\end{tabular} & $-.274 * *$ & $-.257 * *$ & 1 & & & & & & & \\
\hline \begin{tabular}{|c|} 
Physical and \\
mental \\
health
\end{tabular} & $-.485 * *$ & $-.534 * *$ & $.518 * *$ & 1 & & & & & & \\
\hline Workload & $.570 * *$ & $.582 * *$ & $-.351 * *$ & $-.345 * *$ & 1 & & & & & \\
\hline \begin{tabular}{|l|} 
Environmen \\
tal pressure
\end{tabular} & $.521 * *$ & $.532 * *$ & $-.411 * *$ & $-.322 * *$ & $.727 * *$ & 1 & & & & \\
\hline \begin{tabular}{|c|} 
Values \\
\end{tabular} & $-.620 * *$ & $-.538 * *$ & $.580 * *$ & $672 * *$ & $-.508 * *$ & $-.500 * *$ & 1 & & & \\
\hline \begin{tabular}{|c|} 
Compensatio \\
$n$ and \\
benefits
\end{tabular} & $-.397 * *$ & $-.400 * *$ & $314 * *$ & $.384 * *$ & $-.524 * *$ & $-.423 * *$ & $.540 * *$ & 1 & & \\
\hline \begin{tabular}{|c|}
$\begin{array}{c}\text { Promotion } \\
\text { training }\end{array}$ \\
\end{tabular} & $-.520 * *$ & $-.498 * *$ & $488 * *$ & $605 * *$ & $-.527 * *$ & $-.512 * *$ & $697 * *$ & $651 * *$ & 1 & \\
\hline $\begin{array}{c}\text { Interpersona } \\
l \\
\text { relationship }\end{array}$ & $-.446 * *$ & $-.547 * *$ & $415^{* *}$ & $.591 * *$ & $-.460 * *$ & $-.420 * *$ & $651 * *$ & $.581 * *$ & $830 * *$ & 1 \\
\hline
\end{tabular}

\section{F. Regression analysis}

The results of the regression analysis are shown in "Table VII". As can be seen from "Table VII", demographic variables such as gender, age, education, marital status, years of work, monthly income, and job level have no significant effect on emotional failure, depersonalization and low sense of achievement. Under Model 1, the effect of independent variable workload on emotional failure is significantly positively correlated, while values are significantly negatively related to the level of emotional failure. Under Model 2, independent variables like workload, environmental pressure and promotion training are significantly positively correlated with the level of depersonalization, and physical and mental health, interpersonal relationships are significantly negatively correlated with the level of depersonalization. Under
Model 3, the independent physical and mental health is significantly positively correlated with the low sense of achievement (the higher the score for the low sense of achievement, the stronger the individual's sense of achievement), and the interpersonal relationship is significantly negatively correlated with the low sense of achievement, which means that the healthier the body and mind, the more the sense of achievement, and the more harmonious the interpersonal relationship, the lower the sense of achievement. Under Model 4, demographic variables like working years, positional levels, and job burnout levels are significantly positively correlated; monthly income is significantly negatively related to job burnout levels; independent variable workload is significantly positively related to job burnout levels, and interpersonal relationships are 
is partially verified.

TABLE VII. RESULTS OF REGRESSION ANALYSIS

\begin{tabular}{|c|c|c|c|c|c|}
\hline \multicolumn{2}{|c|}{ Independent variable } & $\begin{array}{c}\text { Model 1 } \\
\text { (dependent } \\
\text { variable = } \\
\text { emotional } \\
\text { failure) }\end{array}$ & $\begin{array}{l}\text { Model } 2 \text { (dependent } \\
\text { variable = } \\
\text { depersonalization) }\end{array}$ & $\begin{array}{l}\text { Model } 3 \text { (dependent } \\
\text { variable = low sense } \\
\text { of achievement) }\end{array}$ & $\begin{array}{l}\text { Model } 4 \text { (dependent } \\
\text { variable = job } \\
\text { burnout) }\end{array}$ \\
\hline \multicolumn{2}{|c|}{ Constant } & $2.722 * * *$ & $2.202 * * *$ & -.322 & $1.534 * * *$ \\
\hline \multicolumn{2}{|c|}{ Gender } & -.019 & -.086 & -.124 & -.076 \\
\hline \multicolumn{2}{|c|}{ Age } & -.037 & -.026 & .084 & .007 \\
\hline \multicolumn{2}{|c|}{ Education level } & .043 & .026 & .158 & .076 \\
\hline \multicolumn{2}{|c|}{ Years of working } & .047 & .101 & .522 & $.223^{* * *}$ \\
\hline \multicolumn{2}{|c|}{ Marital status } & .026 & .066 & -.009 & .028 \\
\hline \multicolumn{2}{|c|}{ Positional level } & .118 & -.043 & .269 & $.115^{*}$ \\
\hline \multicolumn{2}{|c|}{ Monthly income } & -.139 & -.071 & -.152 & $-.121 *$ \\
\hline \multicolumn{2}{|c|}{$\begin{array}{l}\text { Physical and mental } \\
\text { health }\end{array}$} & -.152 & $-.277 * * *$ & $.360 * * *$ & -.023 \\
\hline \multicolumn{2}{|c|}{ Workload } & $.396 * * *$ & $.322 * * *$ & .117 & $.278 * * *$ \\
\hline \multicolumn{2}{|c|}{ Environmental pressure } & .133 & $.158 * *$ & -.045 & .082 \\
\hline \multicolumn{2}{|c|}{ Values } & $-.438 * * *$ & -.050 & .163 & -.108 \\
\hline \multicolumn{2}{|c|}{$\begin{array}{c}\text { Compensation and } \\
\text { benefits }\end{array}$} & .057 & .005 & -.082 & -.007 \\
\hline \multicolumn{2}{|c|}{ Promotion training } & -.160 & $.247 * *$ & .234 & .107 \\
\hline \multicolumn{2}{|c|}{$\begin{array}{l}\text { Interpersonal } \\
\text { relationship }\end{array}$} & .117 & $-.352 * *$ & $-.271 * *$ & $-.169 *$ \\
\hline \multirow{3}{*}{$\begin{array}{c}\text { Model } \\
\text { informati } \\
\quad \text { on }\end{array}$} & $\begin{array}{c}\text { Adjusted } \\
R^{2}\end{array}$ & .463 & .489 & .599 & .234 \\
\hline & $F$ & 13.247 & 14.603 & 22.233 & 5.353 \\
\hline & $D W$ & 1.360 & 1.312 & 1.144 & 1.209 \\
\hline
\end{tabular}

a. Note: $* \mathrm{p}<0.10, * * \mathrm{p}<0.05, * * * \mathrm{p}<0.01$

It can be seen that for young employees engaged in the express delivery industry in Guangdong province, the longer the working years, the higher the level of job burnout; the higher the position, the lower the monthly income, the greater the workload, the more nervous the interpersonal relationship, and the more prone to job burnout. It is particularly noteworthy here that for young employees engaged in the express delivery industry, too harmonious interpersonal relationships actually make them feel unfulfilled. Why would such phenomenon happen? The research object of this article is young employees. In the sample, $55.5 \%$ are under the age of 25 , and $83.5 \%$ are employees with a junior college degree or below. From the perspective of China's background, this is a group of post-90s employees, a generation that has grown up with abundant material conditions. According to McClelland's theory of achievement motivation, these post-90s employees are at a time when achievement needs are dominant. In order to meet their inner needs for achievement, they are willing to devote themselves to work for a long time, they are willing to challenge and compete with colleagues, and they hope to get more opportunities from work and get more sense of achievement. From the perspective of age, young employees in this age group have strong self-esteem. They like to compare themselves with their peers. They hope that the respect they receive comes from work achievements, otherwise they will feel that they lose face and will consciously do something that disrupts relationships between colleagues.

\section{G. Robustness test}

To further verify the reliability of the results, a robustness test is performed. The principal factor analysis is used to extract the common factors of the dependent and independent variables as the dependent and independent variables, and the regression analysis is performed. The results are shown in "Table VIII". The conclusions are consistent with "Table VII", showing that the model has certain stability. 
TABLE VIII. ROBUSTNESS TEST RESULTS

\begin{tabular}{|c|c|c|c|c|c|}
\hline \multicolumn{2}{|c|}{ Independent variable } & $\begin{array}{c}\text { Model 5 } \\
\text { (dependent } \\
\text { variable QX) } \\
\end{array}$ & $\begin{array}{c}\text { Model 6 } \\
\text { (dependent } \\
\text { variable = QG) } \\
\end{array}$ & $\begin{array}{l}\text { Model } 7 \text { (dependent } \\
\text { variable = DC) }\end{array}$ & $\begin{array}{c}\text { Model } 8 \text { (dependent } \\
\text { variable = JOB })\end{array}$ \\
\hline \multicolumn{2}{|c|}{ Constant } & .086 & .261 & $-1.284 * * *$ & -.312 \\
\hline \multicolumn{2}{|c|}{ Gender } & -.019 & -.118 & -.114 & -.084 \\
\hline \multicolumn{2}{|c|}{ Age } & -.042 & -.026 & .077 & .003 \\
\hline \multicolumn{2}{|c|}{ Education level } & .052 & .031 & $.150^{*}$ & .078 \\
\hline \multicolumn{2}{|c|}{ Years of working } & .056 & .135 & $.489 * * *$ & $.227 * * *$ \\
\hline \multicolumn{2}{|c|}{ Marital status } & .030 & .092 & -.011 & .037 \\
\hline \multicolumn{2}{|c|}{ Positional level } & .134 & -.060 & $.250 * * *$ & .108 \\
\hline \multicolumn{2}{|c|}{ Monthly income } & -.166 & -.101 & -.143 & $-.137 *$ \\
\hline \multicolumn{2}{|c|}{$S X$} & -.120 & $-.255 * * *$ & $.235 * * *$ & -.047 \\
\hline \multicolumn{2}{|c|}{$G F$} & $.297 * * *$ & $.291 * * *$ & .063 & $.217 * * *$ \\
\hline \multicolumn{2}{|c|}{$H J$} & .122 & $.156^{* * *}$ & -.025 & .084 \\
\hline \multicolumn{2}{|c|}{$J G$} & $-.366^{* * * *}$ & -.050 & .113 & -.101 \\
\hline \multicolumn{2}{|c|}{$X F$} & .057 & .005 & -.054 & .003 \\
\hline \multicolumn{2}{|c|}{$J P$} & -.145 & $.206^{*}$ & .125 & .062 \\
\hline \multicolumn{2}{|c|}{$R G$} & .102 & $-.327 * * *$ & $-.165^{*}$ & $-.130 *$ \\
\hline \multirow{3}{*}{$\begin{array}{c}\text { Model } \\
\text { information }\end{array}$} & $\begin{array}{c}\text { Adjusted } \\
R^{2} \\
\end{array}$ & .463 & .487 & .599 & .279 \\
\hline & $\boldsymbol{F}$ & 13.233 & 14.479 & 22.228 & 6.509 \\
\hline & $D W$ & 1.359 & 1.307 & 1.140 & 1.219 \\
\hline
\end{tabular}

a. Note: * $\mathrm{p}<0.10, * * \mathrm{p}<0.05, * * * \mathrm{p}<0.01$. Among them, the common factors of $\mathrm{QX}$ for emotional failure, depersonalization, low achievement, job burnout, physical and mental health, workload, environmental stress, values, compensation and benefits, promotion training and interpersonal relationships are: QX, QG, DC, JOB, SX, GF, HJ, JG, XF, JP, RG

\section{CONCLUSION AND RECOMMENDATION}

\section{A. Different conclusions of job burnout among young employees in the express delivery industry in Guangdong province}

According to the analysis of the survey results of job burnout among young employees in the express delivery industry in Guangdong province, it can be seen that there is a moderate level of job burnout among young employees in the express delivery industry in Guangdong province. From the test results, there are significant differences in the levels of job burnout among young employees of different genders, ages, education levels, years of work, job levels and monthly income. Male's job burnout levels are higher than females, and they are more likely to feel more fulfilled than females; the lower the age, the lower the education level, the shorter the number of years of work, and the lower the income of the first-line unmarried basic-level employees, the more likely they are to experience emotional breakdown and depersonalization, and the more likely they are to feel fulfilled. The easy-to-satisfy sense of accomplishment virtually reduces the level of job burnout. Hypothesis 1 is verified.

\section{B. The conclusion of influencing factors and job burnout}

Among the independent variables of physical and mental health, workload, environmental stress, values, compensation and benefits, promotion training and interpersonal relationships, workload and interpersonal relationships have the greatest impact on the job burnout of young employees in Guangdong province. Specifically, in terms of the three dimensions of job burnout, workload and values have the greatest impact on emotional failure. Workload, environmental stress, promotion training, physical and mental health, and interpersonal relationships all affect the depersonalization of young employees. Physical and mental health and interpersonal relationships have the greatest impact on low sense of achievement. Hypothesis 2 is partially verified.

\section{Recommendations}

1) Improving working environment: Based on the two-factor theory, the working environment is a hygiene factor. If the hygiene factor is not met, it is easy for employees to have dissatisfaction, negative work delays, and even cause job burnout. In the express delivery industry, front-line employees are the key factors to improve the efficiency and quality of the "last 
mile". Enterprises should pay attention to improving their working environment, optimizing travel equipment and travel routes to increase employees' satisfaction and reduce negative emotions.

2) Reducing workload and enriching work content: Most posts in express delivery companies have a large workload and long working hours, especially for frontline positions, which consume a lot of physical energy every day. And their work content even has hidden safety hazards. The pressure brought by this kind of work has caused employees to be in a state of fatigue for a long time, and their enthusiasm for work has gradually disappeared. Enterprises should do a good job in related measures, improve urban express terminal services in terms of delivery time, and gradually expand smart delivery services such as smart express boxes and courier collection stations to reduce delivery time, improve delivery efficiency, and shorten daily working hours. Enterprises should also arrange flexible working mechanism, reasonably divide the delivery area, reduce the time on the way to and from the delivery, implement scientific management, and reasonably calculate the physical and mental workload of each employee so as to arrange the daily delivery volume. Enterprises should appropriately adopt a job rotation mechanism to reduce employees' burnout due to a single job content and improve their sense of work accomplishment.

3) Improving the incentive mechanism and providing more opportunities for growth: From the perspective of two-factor theory, the factors that can really motivate employees are: firstly, a sense of accomplishment at work; secondly, more opportunities for performance at work; thirdly, full of fun at work; fourthly, awards for outstanding work; fifthly, more opportunities for promotion and development and full of expectations for the future. Express companies should start from the above factors, continue to improve the company's incentive mechanism and promotion mechanism, increase internal incentives while increasing external incentives, provide career counseling and more vocational skills training opportunities for young employees, and further improve their professional sense of accomplishment, thereby reducing the job burnout caused by low achievement. Enterprises should improve the compensation system, enrich employee benefits, reject thepiecework system, increase employees' psychological rewards, and reduce negative emotions and depersonalized behaviors caused by excessive life pressure caused by low income.

4) Creating a harmonious corporate competition culture: The construction of a harmonious corporate culture is conducive to creating a good working atmosphere. For employees in the express delivery industry, they can relax their mind and body and reduce emotional failure. Senior leaders in the express delivery industry should pay attention to the care of front-line employees, care for the needs of grass-roots employees, pay attention to their mental health, improve communication channels and do well in psychological counseling and communication. They need to strengthen team building, cultivate the team spirit and struggle consciousness of employees, satisfy employees' sense of accomplishment and make them feel the sense of collective belonging, thereby reducing the emotional failure caused by emotional tension.

\section{References}

[1] Maslach C, Jackson S. The measurement of experienced burnout[J]. Journal of Occupational Behaviour, 1981, (2): 99113

[2] Maslach C, Schaufeli WB, Leiter MP. Job Burnout[J]. Annual Reviews of Psychology, 2001, 52: 397-422.

[3] Marco Ferrara, Daniela Converso, Sara Viotti. Patient satisfaction and occupational health of workers in hospital care setting: Associations and reciprocity[J]. Health, 2013, (10): 1622-1628

[4] Wang Wenyan. Viewing the Job Burnout of Post-80s Employees from the Perspective of Career Planning [D] Beijing: Capital University of Economics and Business, 2009. (in Chinese)

[5] Zhang Jinmei. Development of Military Burnout Scale [D]. Shanghai: Second Military Medical University, 2011. (in Chinese)

[6] Li Fengrong. A Summary of Enterprise Employees' Job Burnout and Its Countermeasures $[\mathrm{J}]$. China Management Informationization, 2015, (23): 101-103. (in Chinese)

[7] Xiao Zeren. Study on Job Burnout and Countermeasures of Middle-level Managers in Company A [D]. Chengdu: University of Electronic Science and Technology of China, 2016. (in Chinese)

[8] Li Rongyu. An Empirical Study on Auxiliary Police's Job Burnout from the Perspective of the Theory of Matching between People and Organizations [J]. Jingyue Xuebao, 2018, (4): 114-121. (in Chinese)

[9] Haiyan Kong, Ning Sun, Qi Yan. New generation, psychological empowerment[J]. International Journal of Contemporary Hospitality Management, 2016, 2811: 2553 2569.

[10] Liu Bingfan. Research and Management Countermeasures of Employee Burnout of JN Branch of China Construction Bank [D]. Shandong: Shandong University, 2019. (in Chinese)

[11] Zhang Yan. Study on Job Burnout of Employees in Handan F Group [D]. Hebei: Hebei Engineering University, 2018. (in Chinese)

[12] Yu Jufen, Ma Zhiqun. A Survey of Job Burnout and Professional Values of Clinical Nurses in Leshan City [J]. Nursing Practice and Research, 2014, 11 (5): 110-113. (in Chinese)

[13] Zhao Lanfang. Research on Quantitative Relationship Model Between Job Burnout and Performance Evaluation of Young Teachers in Colleges and Universities [J]. Journal of Guangdong Polytechnic Normal University, 2017, 3803: 65-70. (in Chinese) 
[14] Chen Lulu, Pan Liuyan, Xu Mingjin, et al. The Relationship Between Job Stress and Job Burnout of Police in 18 Prisons in Guangxi: The Mediating Role of Psychological Capital [J]. Modern Preventive Medicine, 2016, 43 (2): 230-233. (in Chinese)

[15] Dennis Reynolds. Burnout in full service chain restaurants[J]. The Cornell Hotel and restaurant administration quarterly, 1993, 34(2): 62-68.

[16] Jin Renmin, Xu Zuhui. Analysis on the Factors of Job Burnout and the Effectiveness of Prediction Models [J]. Journal of Zhengzhou Institute of Aeronautical Industry Management, 2016, 34 (4): 103-109. (in Chinese)

[17] Han Jing, Cheng Huagang, Shi Xinglian. The Effect of Organizational Support on the Job Burnout of Clinicians in the Top Three Hospitals of Tangshan City [J]. Occupation and Health, 2018, 34 (12): 1605-1608 + 1612. (in Chinese)

[18] Zhou Pengfei. Analysis on the Influencing Factors of Job Burnout of Knowledge-based Workers and Its Intervention [J]. Journal of Shiyan Vocational and Technical College, 2010, 23 (2): 43-46. (in Chinese)

[19] Nie Jianing. Study on Job Burnout of Young Employees of SH Materials Group [D]. Inner Mongolia: Inner Mongolia University, 2019. (in Chinese)

[20] Ran Haihe. Job Burnout and Countermeasures of Library Staff Based on Ecological Model [J]. Office Business, 2019, (11): 140-141. (in Chinese)

[21] Hu Xiuli, Guo Huimin, Chen Yanhe. Investigation and Analysis of Job Burnout of Young Employees in Enterprises [J]. Chinese and Foreign Entrepreneurs, 2016, (22): 163. (in Chinese)

[22] Wang Xi. Study on the Factors Influencing the Job Burnout of Employees in LA Rural Commercial Bank [D]. Beijing: North China University of Technology, 2019. (in Chinese) 